\title{
Effects of heat shock on seed germination of Turkish red pine (Pinus brutia)
}

\author{
Efectos de choque térmico sobre la germinación de semillas de pino rojo de Turquía (Pinus brutia)
}

\author{
Melih Boydak ${ }^{a}$, Servet Caliskan ${ }^{b *}$ \\ ${ }^{a}$ Is1k University, Faculty of Fine Arts, 34398, Maslak, Istanbul, Turkey.

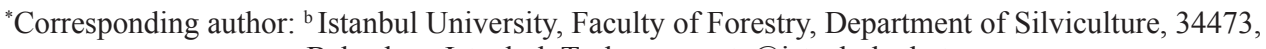 \\ Bahceköy, Istanbul, Turkey, servetc@istanbul.edu.tr
}

\begin{abstract}
SUMMARY
Fire plays an important ecological role in Mediterranean-type ecosystems. Many Mediterranean plant species exhibit enhanced germination capacity when exposed to heat. In the present study, the effect of high temperatures and exposure times on germination of Turkish red pine (Pinus brutia) was analyzed in order to reveal the response of seeds to fire and the implications on species regeneration. Seeds were heated to a range of temperatures (from 75 to $170{ }^{\circ} \mathrm{C}$ ) and exposure times (from 30 seconds to 30 minutes) similar to those obtained in surface soil layers during natural fires. In total, twenty treatments were performed. Seed germination percentages and germination values were calculated for each treatment. The results of ANOVA performed for germination values showed that temperature had a significant effect. Germination percentages increased in thermal treatments at $70{ }^{\circ} \mathrm{C}$ for $10,15,20,25$, and $30 \mathrm{~min}$; at $105^{\circ} \mathrm{C}$ for $10,15,20$, and $25 \mathrm{~min}$, and at $130{ }^{\circ} \mathrm{C}$ for 1 and $2 \mathrm{~min}$. The increase in both temperature and exposure times generally decreased the germination percentage especially at $130{ }^{\circ} \mathrm{C}$ and over in comparison with the control. Maximum germination percentage was reached in the treatment at $130{ }^{\circ} \mathrm{C}$ for $1 \mathrm{~min}$ while the minimum germination was reached at $130{ }^{\circ} \mathrm{C}$ for $10 \mathrm{~min}$.
\end{abstract}

Key words: fire, heat treatment, high temperature, Mediterranean, soil seed bank.

\section{RESUMEN}

El fuego juega un importante papel ecológico en los ecosistemas de tipo mediterráneo. Muchas especies de plantas del Mediterráneo exhiben una capacidad mejorada de germinación cuando se exponen al calor. En el presente estudio, el efecto de altas temperaturas y los tiempos de exposición sobre la germinación de pino rojo de Turquía (Pinus brutia) fue analizado con el fin de revelar la respuesta de las semillas al fuego y las implicaciones en la regeneración de la especie. Las semillas se calentaron en un rango de temperaturas (75 a $170{ }^{\circ} \mathrm{C}$ ), con tiempos de exposición (30 segundos a 30 minutos) similares a los obtenidos en las capas superficiales del suelo durante los incendios naturales. En total se realizaron veinte tratamientos. Se calcularon los porcentajes de germinación de la semilla y los valores de germinación para cada tratamiento. Los resultados de ANOVA realizados para los valores de germinación, mostraron que la temperatura tuvo un efecto significativo. Los porcentajes de germinación aumentaron en los tratamientos térmicos a $70{ }^{\circ} \mathrm{C}$ durante $10,15,20,25$ y $30 \mathrm{~min}$; a $105^{\circ} \mathrm{C}$ durante $10,15,20$ y $25 \mathrm{~min}$, y a $130^{\circ} \mathrm{C}$ durante 1 y 2 min. El aumento de la temperatura y los tiempos de exposición generalmente disminuyeron el porcentaje de germinación, especialmente a $130{ }^{\circ} \mathrm{C}$ y superior en comparación con los controles. El porcentaje máximo de germinación se alcanzó en el tratamiento a $130{ }^{\circ} \mathrm{C}$ durante 1 minuto, mientras se llegó a la germinación mínima a $130{ }^{\circ} \mathrm{C}$ durante $10 \mathrm{~min}$.

Palabras clave: fuego, tratamiento térmico, alta temperatura, mediterráneo, banco de semillas del suelo.

\section{INTRODUCTION}

Turkish red pine is one of the main tree species used in reforestation activities in the Mediterranean region with Aleppo pine. Pinus brutia Ten. is a tree species that is well adapted to forest fires with its remarkably short juvenile phase, cone characteristics, seed ecology and physiology, seed dispersal period, bark thickness and resin content, etc. (Boydak et al. 2006). Several studies carried out in the Mediterranean basin give information about the postfire regeneration in P. brutia and Pinus halepensis Mill. ecosystems and their fire-adapted characteristics. Trabaud
(2000) explains that pine forest vegetation in Mediterranean ecosystems is more flammable than the pine itself. Easy flammability of P. brutia and P. halepensis and their post-fire regeneration are not considered to be a contradiction but a balance of fire-adapted ecosystems. However, P. brutia can regenerate with and without fire (Boydak et al. 2006).

Canopy seed banks (P. brutia and P. halepensis) or soil seed banks (Cistaceae and Leguminosae) are the sources of seeds for post-fire regeneration in Mediterranean ecosystems. Closed cones (canopy seed bank) are stimulated to open and disperse the seed by fire or heat. Heat 
also overcomes the dormancy of $P$. brutia and stimulates germination by softening the seed coats of hard seeded plants (Cistaceae and Leguminosae) (Thanos 1999). The expansion of Cistaceae and Leguminosae populations is often limited to the post-fire conditions (Arianoutsou and Thanos 1996, Thanos 1999, Arianoutsou and Ne'eman 2000). The results of the research conducted in Samos Island, Greece in 1982 revealed that $P$. brutia, Cistus species and Leguminosae species had an important role in postfire regeneration (Thanos et al. 1989) and the total average density of $P$. brutia seedlings in six and ten years following the fire was the same $\left(0.15\right.$ per $\left.\mathrm{m}^{2}\right)$ (Thanos and Marcou 1993). After a forest fire (in 1989) at a 60-year old P. brutia forest (Thasos Island, Greece), on average 2-6 pine seedlings per $\mathrm{m}^{2}$ were recorded by the end of the recruitment period (May 1990) and the density was stabilized at about 0.6-2 seedlings $\mathrm{m}^{-2}$ in five years (Spanos et al. 2000).

The aim of the present study is to investigate the effect of high temperature and exposure times on P. brutia seeds in order to reveal the response of seeds lying on soil, in surface soil layers and in the scorched cones after forest fires. Thus, to understand whether they may stay alive and contribute to post fire regeneration or not. In relation to the aim, the hypothesis of the study is that different heat shock treatments have no effect on germination percentage and germination value of the seeds of P. brutia.

\section{METHODS}

Seed material. Cones were collected by the Turkish Ministry of Forest and Water Affairs, Forest Tree Seeds and Tree Breeding Research Directorate from the natural P. brutia seed stand of 66 years of age situated in Marmaris-Çetibeli $\left(37^{\circ}\right.$ 00 ' 17 " N latitude, $28^{\circ} 19$ ' 42" E longitude, altitude $60 \mathrm{~m}$ ). After their extraction from the cones, seeds were put in partially sealed small glass jars and put in a refrigerator at $+5{ }^{\circ} \mathrm{C}$ till the tests.

Heat-shock treatments and germination tests. Seeds were heated for different periods of time to simulate the effects of fire. Considering fire behavior, a set of treatment temperatures (75-105-130-150-170 ${ }^{\circ} \mathrm{C}$ ) and exposure times (30 sec, 1-2-3-7-10-15-20-25-30 min) were selected. After the treatments, germination tests were carried out at alternating temperatures from 20 to $30{ }^{\circ} \mathrm{C}$ in the Jacobsen apparatus. Seeds were exposed to $20^{\circ} \mathrm{C}$ for 16 hours and to $30^{\circ} \mathrm{C}$ for 8 hours. During the treatment period at $30^{\circ} \mathrm{C}$, seeds were also subjected to about 1,400 lux fluorescent light. Four replicates of 100 seeds were used per treatment. Seeds were considered as germinated when radicles grew more than $2 \mathrm{~mm}$ long from the seed and were removed. Seeds were checked every two days for 28 days.

Statistical analyses. Germination data were expressed as germination percentage (GP) and germination value (GV). GP is the percentage of the seeds that germinated at the end of the test and GV was calculated according to the following equation (Djavanshir and Pourbeik 1976):

$$
G V=\frac{\sum D G S}{N} \times \frac{N_{g s}}{100} \times 10
$$

Where, $\mathrm{GV}=$ germination value, $\mathrm{DGS}=$ daily germination speed, $\mathrm{N}=$ frequency or the number of DGS that are calculated during the test, $\mathrm{N}_{\mathrm{gs}}=$ number of germinated seeds, 10 is the constant value.

In order to find out the normal distribution of residuals and homogeneity of variances prior to the analyses of variance, the germination percentages were transformed using arcsine transformation. The significance of the fixed effects was tested with the $F$ test. The following linear models were used for the analysis:

$$
y_{i j}=\mu+T_{i}+e_{i j}
$$

Where, $y_{i j}=$ observation of $j$-th germination of the $i$-th treatment, $\mu=$ overall mean, $T_{i}=$ effect of treatment, and $e_{i j}$ is the error;

$$
y_{i j k}=\mu+K_{i}+F_{j}+K F_{i j}+e_{i j k}
$$

Where, $y_{i j k}=$ observation of $k$-th germination of the $i$ -th exposure time of the $i$-th temperature, $\mu=$ overall mean, $K_{i}=$ effect of temperature, $F_{j}=$ effect of exposure time, $K F_{i j}=$ interaction effect of temperature-exposure time and $e_{i j}=$ error.

Following the ANOVA, when significant effects were detected, Duncan's multiple range test was used to determine significant differences between the means $(P<0.05)$

\section{RESULTS}

The ANOVA applied to the germination data showed significant differences among the treatments for both germination percentages and germination values $(P<0.0001)$ (table 1). The analyses of variances of germination values also indicated significant effects of temperature (tables 2 and 3). Maximum germination percentage (70.3\%) was reached during the treatment at $130{ }^{\circ} \mathrm{C}$ for $1 \mathrm{~min}$ while the minimum germination ( $4 \%$ ) was reached at $130{ }^{\circ} \mathrm{C}$ for 10 min (figure 1 and table 4).

In general, the germination of $P$. brutia seeds was not significantly influenced by temperatures from 75 to 105 ${ }^{\circ} \mathrm{C}$. On the other hand, a negative influence on germination was observed when temperatures were higher than $130^{\circ} \mathrm{C}$ and exposures times increased (figures 2 and 3). At the temperature of $130{ }^{\circ} \mathrm{C}$ and above, P. brutia seeds were more sensitive to the exposure time than to temperatures (figure 4). 
Table 1. ANOVA results regarding the effects of heat shock (treatment) on germination percentage and germination value in Pinus brutia seeds.

Resultados del ANDEVA de los efectos de choque térmico (tratamiento) en el porcentaje de germinación y el valor de germinación en las semillas de Pinus brutia.

\begin{tabular}{|c|c|c|c|c|c|c|c|}
\hline \multirow{2}{*}{ Source } & \multirow{2}{*}{$\mathrm{df}$} & \multicolumn{3}{|c|}{ Germination percentage } & \multicolumn{3}{|c|}{ Germination value } \\
\hline & & MS & $\mathrm{F}$ & $P$-value & MS & $\mathrm{F}$ & $P$-value \\
\hline Treatments & 20 & 460.68 & 33.95 & $<0.001$ & 132.36 & 30.50 & $<0.001$ \\
\hline Error & 63 & 13.57 & & & 4.34 & & \\
\hline
\end{tabular}

Table 2. Effect of heat shocks of $75^{\circ} \mathrm{C}-10,15,20,25,30 \mathrm{~min}, 105^{\circ} \mathrm{C}-10,15,20,25 \mathrm{~min}$ on the germination of Pinus brutia seeds. Efecto de los choques de calor $75^{\circ} \mathrm{C}-10,15,20,25,30 \mathrm{~min}, 105^{\circ} \mathrm{C}-10,15,20,25$ min sobre la germinación de semillas de Pinus brutia.

\begin{tabular}{|c|c|c|c|c|c|c|c|}
\hline \multirow{2}{*}{ Source } & \multirow{2}{*}{$\mathrm{df}$} & \multicolumn{3}{|c|}{ Germination percentage } & \multicolumn{3}{|c|}{ Germination value } \\
\hline & & MS & $\mathrm{F}$ & $P$-value & MS & $\mathrm{F}$ & $P$-value \\
\hline Temperature & 1 & 7.26 & 0.96 & 0.335 & 39.06 & 13.66 & 0.001 \\
\hline Exposure time & 4 & 6.45 & 0.85 & 0.503 & 3.37 & 1.18 & 0.341 \\
\hline Temperature $\mathrm{X}$ Exposure times & 4 & 0.38 & 0.05 & 0.995 & 3.47 & 1.21 & 0.326 \\
\hline Error & 30 & 7.55 & & & 2.86 & & \\
\hline
\end{tabular}

Table 3. Effect of heat shocks of $150^{\circ} \mathrm{C}-1,2 \mathrm{~min}, 170^{\circ} \mathrm{C}-1,2$ min on the germination of Pinus brutia seeds. Efecto de los choques de calor $150{ }^{\circ} \mathrm{C}-1,2 \mathrm{~min}, 170^{\circ} \mathrm{C}-1,2$ min sobre la germinación de semillas de Pinus brutia.

\begin{tabular}{|c|c|c|c|c|c|c|c|}
\hline \multirow{2}{*}{ Source } & \multirow{2}{*}{ df } & \multicolumn{3}{|c|}{ Germination percentage } & \multicolumn{3}{|c|}{ Germination value } \\
\hline & & MS & $\mathrm{F}$ & $P$-value & MS & $\mathrm{F}$ & $P$-value \\
\hline Temperature & 1 & 100.00 & 5.10 & 0.037 & 74.56 & 11.89 & 0.003 \\
\hline Exposure time & 2 & 21.70 & 1.11 & 0.352 & 18.31 & 2.92 & 0.080 \\
\hline Temperature X Exposure time & 2 & 95.53 & 4.87 & 0.020 & 14.93 & 2.38 & 0.121 \\
\hline Error & 18 & 19.60 & & & 6.27 & & \\
\hline
\end{tabular}

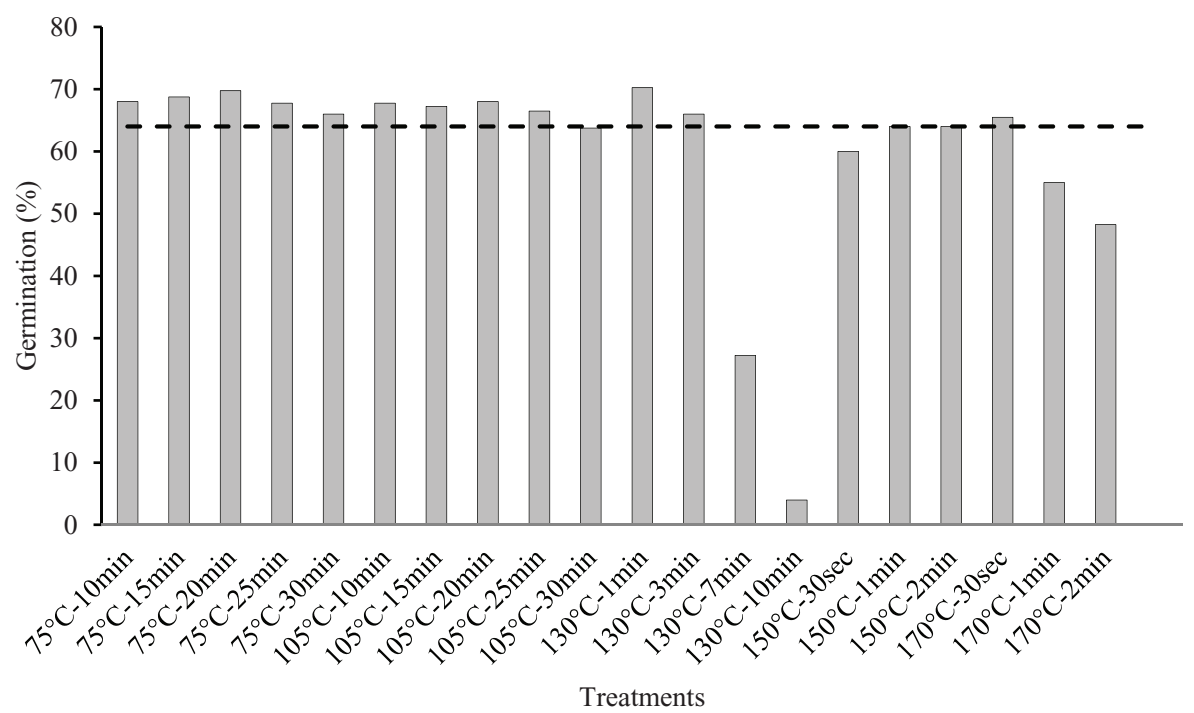

Figure 1. Germination response of Pinus brutia seeds after heat shock treatments of different intensity and exposure times (dashed line represents control).

Respuesta de germinación de semillas de Pinus brutia después de los tratamientos de choque térmico de diferente intensidad y tiempos de exposición (la línea discontinua representa el control). 
Table 4. Effect of heat shocks $\left(75^{\circ} \mathrm{C}-170^{\circ} \mathrm{C}\right)$ on the germination of Pinus brutia seeds.

Efecto de los choques de calor $\left(75^{\circ} \mathrm{C}-170{ }^{\circ} \mathrm{C}\right)$ sobre la germinación de semillas de Pinus brutia.

\begin{tabular}{cccc}
\hline Treatments & $\begin{array}{c}\text { Germination } \\
\text { percentage }\end{array}$ & $\begin{array}{c}\text { Germination } \\
\text { value }\end{array}$ \\
\hline 1 & $75{ }^{\circ} \mathrm{C}-10 \mathrm{~min}$ & $68.0 \mathrm{a}$ & $14.7 \mathrm{ab}$ \\
2 & $75^{\circ} \mathrm{C}-15 \mathrm{~min}$ & $68.8 \mathrm{a}$ & $15.8 \mathrm{ab}$ \\
3 & $75^{\circ} \mathrm{C}-20 \mathrm{~min}$ & $69.8 \mathrm{a}$ & $16.4 \mathrm{a}$ \\
4 & $75^{\circ} \mathrm{C}-25 \mathrm{~min}$ & $67.8 \mathrm{a}$ & $15.6 \mathrm{ab}$ \\
5 & $75^{\circ} \mathrm{C}-30 \mathrm{~min}$ & $66.0 \mathrm{a}$ & $14.8 \mathrm{ab}$ \\
6 & $105^{\circ} \mathrm{C}-10 \mathrm{~min}$ & $67.8 \mathrm{a}$ & $14.7 \mathrm{ab}$ \\
7 & $105^{\circ} \mathrm{C}-15 \mathrm{~min}$ & $67.3 \mathrm{a}$ & $14.1 \mathrm{ab}$ \\
8 & $105^{\circ} \mathrm{C}-20 \mathrm{~min}$ & $68.0 \mathrm{a}$ & $12.5 \mathrm{~b}$ \\
9 & $105^{\circ} \mathrm{C}-25 \mathrm{~min}$ & $66.5 \mathrm{a}$ & $12.7 \mathrm{ab}$ \\
10 & $105^{\circ} \mathrm{C}-30 \mathrm{~min}$ & $63.8 \mathrm{ab}$ & $11.3 \mathrm{bc}$ \\
11 & $130^{\circ} \mathrm{C}-1 \mathrm{~min}$ & $70.3 \mathrm{a}$ & $16.9 \mathrm{a}$ \\
12 & $130^{\circ} \mathrm{C}-3 \mathrm{~min}$ & $66.0 \mathrm{a}$ & $15.9 \mathrm{ab}$ \\
13 & $130{ }^{\circ} \mathrm{C}-7 \mathrm{~min}$ & $27.3 \mathrm{~d}$ & $2.1 \mathrm{f}$ \\
14 & $130^{\circ} \mathrm{C}-10 \mathrm{~min}$ & $4.0 \mathrm{e}$ & $0.1 \mathrm{~g}$ \\
15 & $150{ }^{\circ} \mathrm{C}-30 \mathrm{~s}$ & $60.0 \mathrm{ab}$ & $12.5 \mathrm{~b}$ \\
16 & $150^{\circ} \mathrm{C}-1 \mathrm{~min}$ & $64.0 \mathrm{ab}$ & $13.2 \mathrm{ab}$ \\
17 & $150^{\circ} \mathrm{C}-2 \mathrm{~min}$ & $64.0 \mathrm{a}$ & $12.1 \mathrm{bc}$ \\
18 & $170^{\circ} \mathrm{C}-30 \mathrm{~s}$ & $65.5 \mathrm{a}$ & $11.9 \mathrm{bc}$ \\
19 & $170{ }^{\circ} \mathrm{C}-1 \mathrm{~min}$ & $55.0 \mathrm{bc}$ & $9.1 \mathrm{dc}$ \\
20 & $170{ }^{\circ} \mathrm{C}-2 \mathrm{~min}$ & $48.3 \mathrm{c}$ & $6.3 \mathrm{de}$ \\
21 & $\mathrm{Control}^{\circ}$ & $64.0 \mathrm{ab}$ & $13.8 \mathrm{de}$ \\
\hline
\end{tabular}

Means in the same column followed by the same lowercase letter are not significantly different $(P<0.05)$.

Medias en la misma columna seguidas por la misma letra minúscula no son significativamente diferentes $(P<0,05)$.
The Duncan's test performed on the germination results (GP) of the P. brutia seeds revealed six treatment groups (table 4). The first group consists of the treatments of $75^{\circ} \mathrm{C}-10,15,20,25,30 \mathrm{~min}, 105^{\circ} \mathrm{C}-10,15,20,25 \mathrm{~min}$, $130{ }^{\circ} \mathrm{C}-1,3 \mathrm{~min}, 150^{\circ} \mathrm{C}-2 \mathrm{~min}, 170^{\circ} \mathrm{C}-30 \mathrm{~s}$ and the second group includes $105{ }^{\circ} \mathrm{C}-30 \mathrm{~min}, 150{ }^{\circ} \mathrm{C}-30 \mathrm{sec}, 150{ }^{\circ} \mathrm{C}-1$ min, and the control. The other treatments $\left(170^{\circ} \mathrm{C}-1 \mathrm{~min}\right.$, $170{ }^{\circ} \mathrm{C}-2 \mathrm{~min}, 130^{\circ} \mathrm{C}-7 \mathrm{~min}, 130^{\circ} \mathrm{C}-10 \mathrm{~min}$ ) were grouped individually. But at $150{ }^{\circ} \mathrm{C}-1 \mathrm{~min}$ and $2 \mathrm{~min}$, more than 64 $\%$ of germination was achieved. Besides, more than $55 \%$ and $48 \%$ of germination were also achieved at $170{ }^{\circ} \mathrm{C}-1$ min and 2 min, respectively (table 4 ).

\section{DISCUSSION}

The most effective disturbance in P. brutia forests in the Mediterranean ecosystem is natural or man-made fire. Studies point out that $P$. brutia forests are exposed to highintensity and low-intensity fires almost every 25 years and every nine years, respectively, in Doyran-Antalya, Turkey (Neyiş̧̧i 1986, 1993).

In the present study, P. brutia seeds exposed to heat in an oven for 30 minutes at $105{ }^{\circ} \mathrm{C}$ and two minutes at $150{ }^{\circ} \mathrm{C}$ showed as high germination percentages as the control groups. Under different heat shocks, twelve out of twenty treatments showed better germination results compared to the control groups. Germination declined in three treatments $\left(130{ }^{\circ} \mathrm{C}-7,10 \mathrm{~min}\right.$, and $\left.170{ }^{\circ} \mathrm{C}-2 \mathrm{~min}\right)$. In one of these treatments $\left(130{ }^{\circ} \mathrm{C}-10 \mathrm{~min}\right)$, only $4 \%$ of the seeds survived. Moreover, in two cases $\left(170{ }^{\circ} \mathrm{C}-1 \mathrm{~min}\right.$ and $150^{\circ} \mathrm{C}-30 \mathrm{~s}$ ), germination percentages were also lower than that of the control, but germination percentages were higher than $55 \%$ and $60 \%$, respectively.

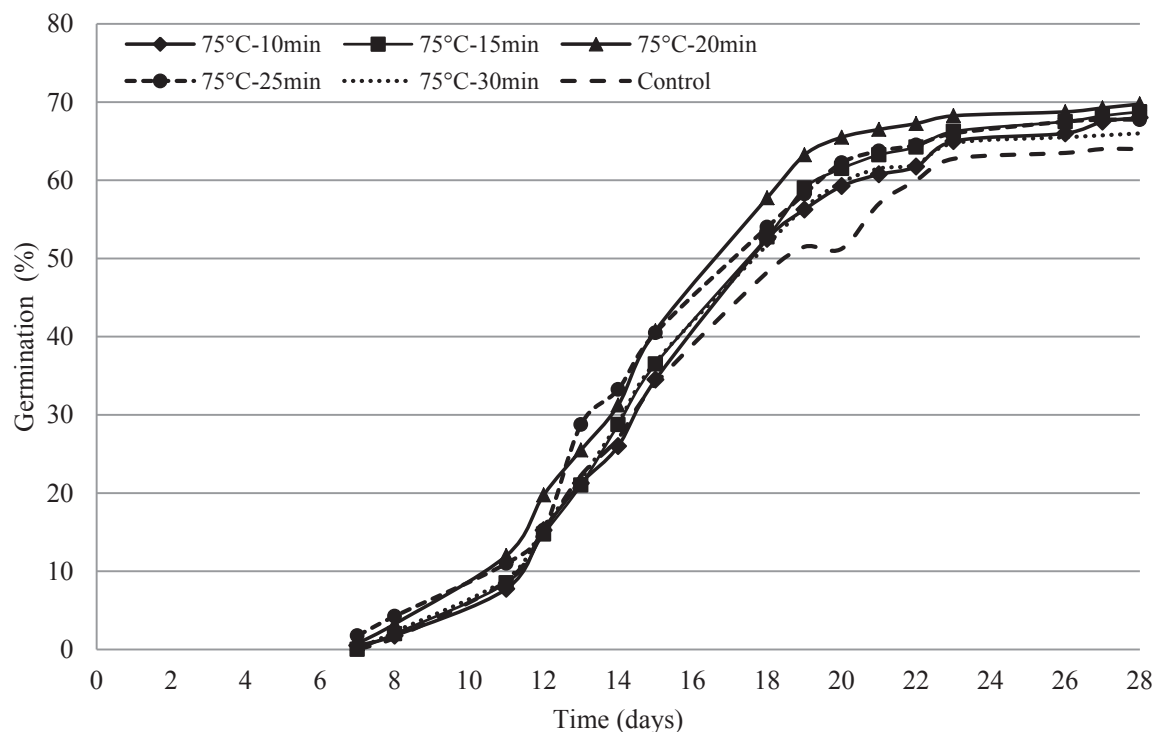

Figure 2. Dynamics of Pinus brutia seed germination after heat shock treatments at $75{ }^{\circ} \mathrm{C}$ in different exposure times.

Dinámica de la germinación de las semillas de Pinus brutia después de los tratamientos de choque térmico, a temperatura $75^{\circ} \mathrm{C}$ a diferentes tiempos de exposición. 
Similar to our results, heated seeds of P. brutia $\left(125^{\circ} \mathrm{C}\right.$ for 20 minutes and $150{ }^{\circ} \mathrm{C}$ for 10 minutes) could maintain their viability. According to the results, there were no significant differences between $40{ }^{\circ} \mathrm{C}$ and $110{ }^{\circ} \mathrm{C}$. Although a sharp decline was recorded in germination rapidly after $110^{\circ} \mathrm{C}$ (Neyiş̧̧i and Cengiz 1985). Besides, higher germina- tions were obtained from the $P$. brutia seeds that were heated at $75{ }^{\circ} \mathrm{C}$ (with $5,10,15$ and 20 minutes) than from the control, and germination percentages were closer to the control at $100^{\circ} \mathrm{C}$ with the same exposure times (Cetin 2010).

On the other hand, in a P. brutia ecosystem, fire heat at $250^{\circ} \mathrm{C}$ on the soil surface decreases to $66^{\circ} \mathrm{C}, 46^{\circ} \mathrm{C}$ and $40^{\circ} \mathrm{C}$

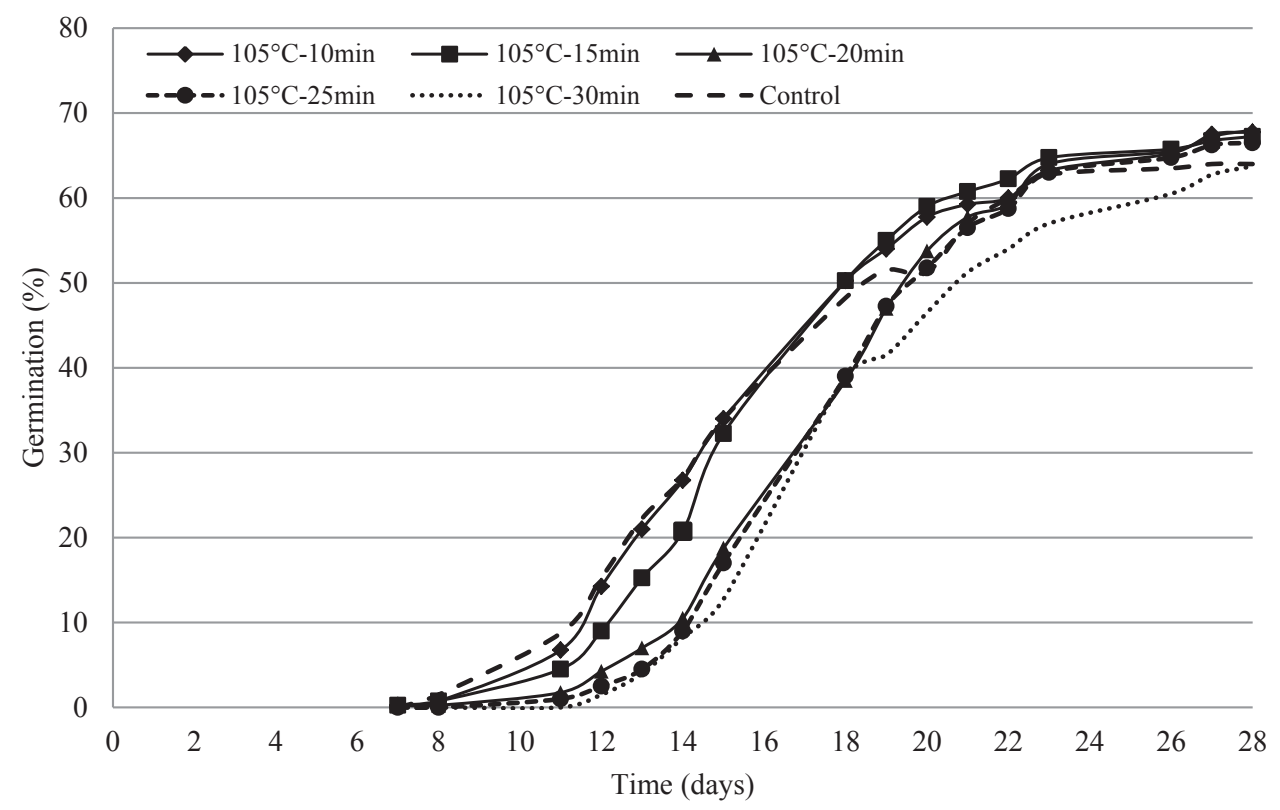

Figure 3. Dynamics of Pinus brutia seed germination after heat shock treatments at $105^{\circ} \mathrm{C}$ in different exposure times.

Dinámica de la germinación de las semillas de Pinus brutia después de los tratamientos de choque térmico, a temperatura $105^{\circ} \mathrm{C}$ a diferentes tiempos de exposición.

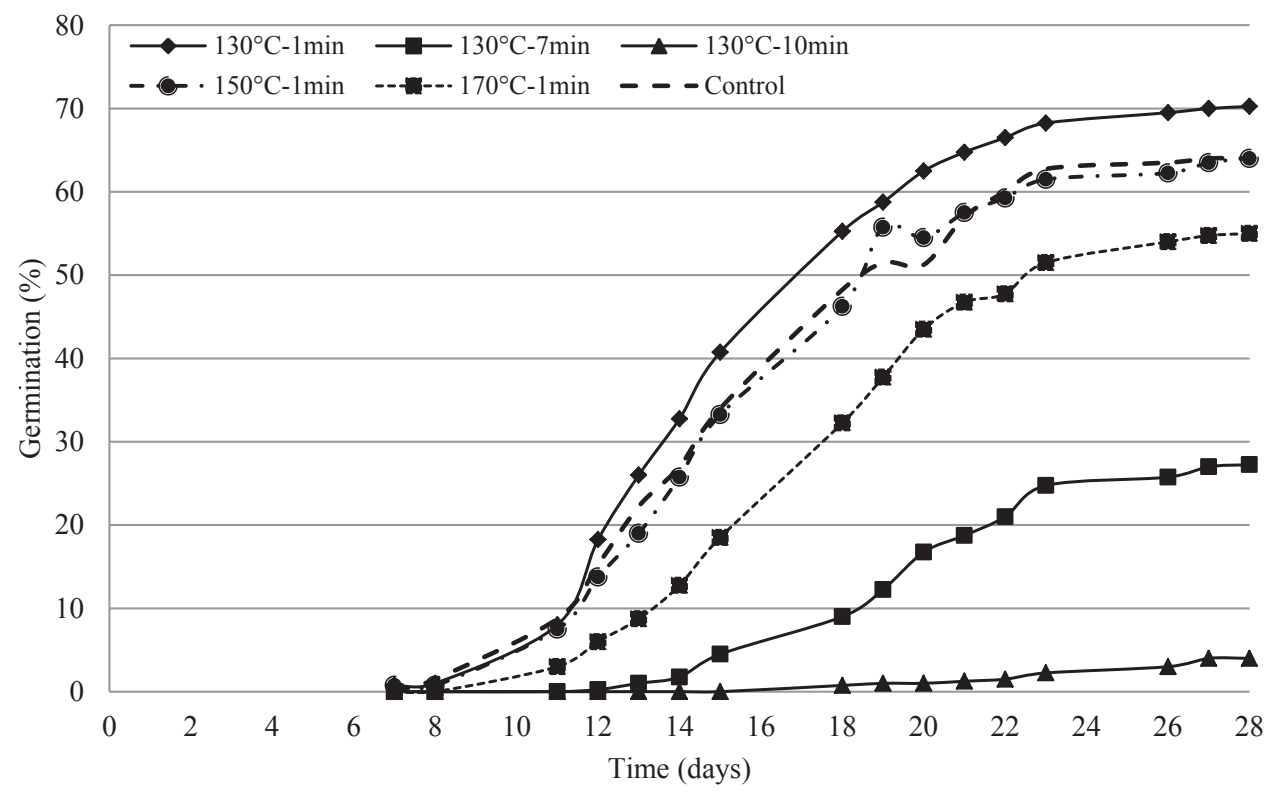

Figure 4. Dynamics of Pinus brutia seed germination after treatment of varying heats $\left(130-150-170{ }^{\circ} \mathrm{C}\right)$ and exposure times.

Dinámica de la germinación de las semillas de Pinus brutia después del tratamiento con diferentes grados de calor $\left(130-150-170{ }^{\circ} \mathrm{C}\right)$ y tiempos de exposición. 
in the soil depths of $2.5 \mathrm{~cm}, 5 \mathrm{~cm}$ and $10 \mathrm{~cm}$, respectively (Neyiş̧̧i 1989). Moreover, in P. brutia forests, post-fire regeneration was achieved by lying scorched cone bearing branches on soil (Eron and Sarıgül 1992). Seeds can remain viable if cones are exposed to a heat range of 367 to $632^{\circ} \mathrm{C}$ for a very short time (Neyişçi and Cengiz 1985). Wright (1931) explained that the oven heat between $65^{\circ} \mathrm{C}$ and $120^{\circ} \mathrm{C}$ could reach the embryo in four minutes. Seed coat thickness of $P$. brutia which constituted a significant fraction of seed weight was high (55.5\%) (Thanos 2000) and this also contributed to the preservation of the seed viability in P. brutia. After the fire in Samos Island (Greece) in 1983, those seeds which were collected from the surface of the burned soil were found to be highly viable (Thanos et al. 1989). Considering these findings we can conclude that some of the P. brutia seeds lying on soil, in surface soil layers and in the scorched cones may survive and contribute to post fire regeneration. Besides, P. brutia disperses seeds throughout the whole year (Ürgenç et al. 1989, Boydak 2004). This could also be accepted as another silvicultural advantage of the survival of $P$. brutia after fire in the Mediterranean ecosystem.

Thousands of hectares of even-aged old and pure P. brutia forests at different locations in the Mediterranean Region of Turkey could be considered as an indirect evidence for the establishment of these forests after fire in addition to the other evidences (Boydak et al. 2006).

Different effects of heat-shock on seed germination of other species have also been demonstrated. For example, Reyes and Trabaud (2009) stated that heat in moderate doses enhanced germination in Cistus monspeliensis L., Melica ciliate L., Bituminaria bituminosa L. C. H. Stirt., Coronilla glauca L., Argyrolobium zanonii, Emerus major Mill., Spartium junceum L. But high temperature $\left(150^{\circ} \mathrm{C}\right)$ inhibited germination of all these species. Núñez and Calvo (2000) also observed that high temperature did not increase the germination in Pinus halepensis and Pinus sylvestris. Silveira and Overbeck (2013) tested the seeds of Fabaceae species and the seeds were exposed to different heat treatments (exposure to $60^{\circ}$ and $80{ }^{\circ} \mathrm{C}$ for 5 minutes, to $100{ }^{\circ} \mathrm{C}$ for two minutes). The effect of heat-shock treatments $\left(60,80,100,120\right.$ and $140{ }^{\circ} \mathrm{C}$ for five min) on the germination of 21 herbaceous species in Central Anatolian steppe was evaluated and it is suggested that the seeds of plant species in Central Anatolian steppes are resistant to low-intensity surface fires (Tavsanoglu et al. 2015). Ribeiro et al. (2013) investigated the effects of heat shocks on seed germination of Brazilian savanna species and only one species presented accelerated germination due to heat treatments. Seeds of the dominant forest species in Chaco were subjected to different experimental heat shock treatments (Jaureguiberry and Díaz 2015). It was found that seed germination of the vast majority of the species studied tolerated low and medium temperature heat-shock treatments, suggesting that these seeds are able to survive moderate intensity fires.

\section{CONCLUSIONS}

In conclusion, the germination of the P. brutia seeds was not affected by low and moderate heat shock. Taking into consideration the above mentioned research results, we may conclude that in P. brutia, during the fires at certain degrees, most seeds in the cones and some seeds on the soil or in the scorched cones may continue to their viability and contribute to regeneration. Thus, under natural and/or man caused forest fire conditions, the abundance post-fire regeneration of $P$. brutia in the Mediterranean basin can be attributed to its seed characteristics either in closed cones (crown seed bank) and seeds on the soil or in the scorched cones which are not affected by low or moderate heat shock. Moreover, during the natural regeneration activities, application of low or moderate intensity prescribed fire can increase success of regeneration.

\section{ACKNOWLEDGEMENTS}

We sincerely thank the Forest Tree Seeds and Tree Breeding Research Directorate, Turkish Ministry of Forest and Water Affairs for seed collection. We also thank Izzet Ipek for his laboratory assistance during the germination tests.

\section{REFERENCES}

Arianoutsou M, G Ne'eman 2000. Post- fire regeneration of natural Pinus halepensis forests in the east Mediterranean Basin. In Ne'eman G, L Trabaud eds. Ecology, biogeography and management of Pinus halepensis and Pinus brutia forest ecosystems in the Mediterranean Basin. Leiden, The Netherlands. Backhuys Publishers. p. 169-189.

Arianoutsou M, C Thanos. 1996. Legumes in the fire prone Mediterranean regions: an example from Greece. International Journal of Wildland Fire 6(2): 77-82.

Boydak M, H Dirik, M Calikoglu. 2006. Biology and silviculture of Turkish red pine (Pinus brutia Ten.). Ankara, Turkey. Ogem-Vak. 253 p.

Boydak M. 2004. Silvicultural characteristics and natural regeneration of Pinus brutia Ten. a review. Plant Ecology 171:153-163.

Cetin B. 2010. Mersin yöresinde kızılçam (Pinus brutia Ten.) kozalak ve tohumuna ait bazı özelliklerin yükseltiye bağlı değişimi. PhD dissertation. Istanbul, Turkey. Istanbul University. $185 \mathrm{p}$.

Djavanshir K, H. Pourbeik. 1976. Germination value-a new formula. Silvae Genetica 25:79-83.

Eron Z, M Sarıül. 1992. Natural regenaration of Pinus brutia Ten. by laying out of cone bearing branches on fire burned areas in Aegean region. Publications of Forestry Research Institute 48:9-37.

Jaureguiberry P, S Díaz. 2015. Post-burning regeneration of the Chaco seasonally dry forest: germination response of dominant species to experimental heat shock. Oecologia 177(3):689-699.

Neyişçi T. 1986. Antalya Doyran yöresi kızılçam (Pinus brutia Ten.) ormanlarında yangınların tarihsel etkileri. Publications of Forestry Research Institute 29:67-91. 
Neyişçi T. 1989. Effects of prescribed burning on soil chemical properties and subsequent seedling growth in Pinus brutia Ten. ecosystems. Ankara, Turkey. Publications of Forestry Research Institute No: 205. 56 p.

Neyişçi T. 1993. Ecological adaptive traits of Pinus brutia Ten. to fires. In International Pinus brutia Symposium. 18-23 October 1993, Marmaris-Turkey. Ankara, Turkey. Forest Ministry. p. 79-84.

Neyişçi T, Y Cengiz. 1985. Effects of heat and ash on the germination and seedling growth of Pinus brutia. Doğa Bilim Dergisi 9(1):121-131.

Núñez MR, L Calvo. 2000. Effects of high temperatures on seed germination of Pinus sylvestris and Pinus halepensis. Forest Ecology and Management 131:183-190.

Reyes O, L Trabaud. 2009. Germination behavior of 14 Mediterranean species in relation to fire factors: smoke and heat. Plant Ecology 202:113-121.

Ribeiro LC, M Pedrosa, F Borghetti. 2013. Heat shock effects on seed germination of five Brazilian savanna species. Plant Biology 15(1):152-157.

Silveira FS, GE Overbeck. 2013. Effect of high temperature on germination of four legumes from a forest-grassland mosaic in Southern Brazil. Biota Neotrop 13(2):331-335.

Spanos IA, EN Daskalakou, CA Thanos. 2000. Postfire, natural regeneration of Pinus brutia forests in Thasos Island, Greece. Acta Oecologica 21(1): 13-20.

Tavşanoğlu Ç, ŞS Çatav, B Özüdoğru. 2015. Fire-related germination and early seedling growth in 21 herbaceous species in Central Anatolian steppe. Journal of Arid Environments 122:109-116.

Thanos CA. 1999. Fire effects on forest vegetation. The case of
Mediterranean pine forests in Greece. In Eftichidis G, P Balabanis, A Ghazi eds. Wildfire management. Proceeding of the advanced study course (6-14 October 1997, Marathon). Athens, Greece. p. 323-334.

Thanos CA. 2000. Ecophysiology of seed germination in Pinus halepensis and Pinus brutia. In Ne'eman G, L Trabaud eds. Ecology, biogeography and management of Pinus halepensis and Pinus brutia forest ecosystems in the Mediterranean Basin. Leiden, The Netherlands. Backhuys Publishers. p. 37-50.

Thanos CA, S. Marcou. 1993. Natural regeneration of Pinus brutia in Samos Island. Key events during the first 10 years of the postfire period. In International Pinus brutia Symposium (18-23 October 1993, Marmaris-Turkey). Ankara, Turkey. Forest Ministry. p. 176-183.

Thanos CA, S Marcou, D Christodoulakis, A Yanitsaros. 1989. Early post-fire regeneration forest ecosystems of Samos Island (Greece): 6 years after. Acta Ecologia 12 (5):633-647.

Trabaud L. 2000. Post-fire regeneration of Pinus halepensis forests in the west mediterranean. In Ne'eman G, L Trabaud eds. Ecology, biogeography and management of Pinus halepensis and Pinus brutia forest ecosystems in the Mediterranean Basin. Leiden, The Netherlands. Backhuys Publishers. p. 257-268.

Ürgenç S, M Boydak, T Özdemir, B Ceylan, Ü Eler. 1989. Kızılçam (Pinus brutia Ten.) meşçerelerinde aralama ve hazırlama kesimlerinin tepe gelişimi ve tohum hasılatına etkileri üzerine araştırmalar. Teknik Bülten 210. Ankara, Turkey. Forestry Research Institute. 69 p.

Wright B. 1931. The effect of high temperatures on seed germination. Journal of Forestry 29(5):679-687.

Recibido: 18.01 .16

Aceptado: 08.04.16 
